\title{
Naturalization of ornamental plant species in public green spaces and private gardens
}

\author{
Katharina Mayer • Emily Haeuser • Wayne Dawson • Franz Essl • \\ Holger Kreft • Jan Pergl • Petr Pyšek • Patrick Weigelt • Marten Winter • \\ Bernd Lenzner $\cdot$ Mark van Kleunen
}

\begin{abstract}
Ornamental horticulture is the most important pathway for alien plant introductions worldwide, and consequently, invasive spread of introduced plants often begins in urban areas. Although most introduced ornamental garden-plant species are locally not naturalized yet, many of them have shown invasion potential elsewhere in the world, and might naturalize when climate changes. We inventoried the planted flora of 50 public and 61 private gardens in Radolfzell, a small city in southern
\end{abstract}

Guest Editors: Mirijam Gaertner, John R.U. Wilson, Marc W. Cadotte, J. Scott MacIvor, Rafael D. Zenni and David M. Richardson/Urban Invasions.

K. Mayer · E. Haeuser · M. van Kleunen ( $\square)$ Ecology, Department of Biology, University of Konstanz, Universitätsstrasse 10, 78467 Konstanz, Germany e-mail: mark.vankleunen@uni-konstanz.de

\section{W. Dawson}

Department of Biosciences, Durham University, South Road, Durham DH1 3LE, UK

\section{F. Essl · B. Lenzner}

Division of Conservation Biology, Vegetation and Landscape Ecology, University of Vienna, 1030 Vienna, Austria
Germany, to investigate whether local naturalization success of garden plants is associated with their current planting frequency, climatic suitability (as assessed with climatic niche modelling) and known naturalization status somewhere in the world. We identified 954 introduced garden-plant species, of which 48 are already naturalized in Radolfzell and 120 in other parts of Germany. All currently naturalized garden plants in Radolfzell have a climatic suitability probability of $\geq 0.75$ and are naturalized in $\geq 13$ out of 843 regions globally. These values are significantly higher than those of garden plants that have not become locally naturalized yet. Current planting frequencies, however, were not related to current naturalization success. Using the identified local naturalization thresholds of climatic suitability and global naturalization frequency, and climate

F. Essl · P. Weigelt

Centre for Invasion Biology, Department of Botany and Zoology, Stellenbosch University, Matieland 7602, South Africa

\section{H. Kreft}

Biodiversity, Macroecology \& Biogeography, University of Göttingen, Büsgenweg 1, 37077 Göttingen, Germany

J. Pergl · P. Pyšek

Institute of Botany, Department of Invasion Ecology, The Czech Academy of Sciences, 25243 Průhonice, Czech Republic 
projections for the years 2050 and 2070, we identified 45 garden-plant species that are currently not naturalized in Radolfzell but are likely to become so in the future. Although our approach cannot replace a full risk assessment, it is well-suited and applicable as one element of a screening or horizon scanning-type approach.

Keywords Climate change - Exotic plants · Horticulture $\cdot$ Horizon scanning $\cdot$ Invasion risk $\cdot$ Nonnative plants $\cdot$ Risk assessment · Urban green areas

\section{Introduction}

For the first time in human history, most people worldwide are living in cities (UN 2015). Thus, public and private gardens, parks and other green infrastructure contribute towards providing important ecosystem services in urban areas such as climate regulation (e.g. Wang et al. 2014; Lin et al. 2016), and have important aesthetic value (e.g. Lindemann-Matthies and Brieger 2016). The spontaneous flora (i.e. not considering the planted flora) of urban areas contains more alien plant species compared to rural areas (Kühn et al. 2004; Aronson et al. 2014), and the planted garden flora in cities frequently contains large numbers of cultivated alien plants (Pergl et al. 2016a). The majority of them are traded in ornamental horticulture, which is the most important pathway for alien plant introductions worldwide (e.g. Germany: Kühn and Klotz 2002; Nehring et al. 2013, Czech Republic: Pyšek et al. 2012a; Britain: Clement and Foster 1994, USA: Mack and Erneberg 2002; Lehan et al. 2013, Australia: Groves 1998, South Africa: Faulkner et al. 2016; Europe: Křivánek et al. 2006;

P. Pyšek

Department of Ecology, Faculty of Science, Charles University, Viničná 7, 12844 Prague 2, Czech Republic

\section{Winter}

German Centre for Integrative Biodiversity Research (iDiv) Halle-Jena-Leipzig, Deutscher Platz 5e, 04103 Leipzig, Germany

\section{M. van Kleunen}

Zhejiang Provincial Key Laboratory of Plant Evolutionary Ecology and Conservation, Taizhou University,

Taizhou 318000, China
Turbelin et al. 2017). Consequently, invasive spread of alien garden plants often begins in urban areas (Dehnen-Schmutz 2011).

While most of these alien garden plants can only survive where planted under intensive management practices, others escape and establish themselves outside gardens without human assistance (Pergl et al. 2016a). Some of these naturalized garden species have become problematic invaders with negative impacts on native biodiversity (Vilà et al. 2010; Pyšek et al. 2012b). Around the globe, the numbers of newly established alien species are still increasing (Seebens et al. 2017). As the eradication and containment of most of these alien species is difficult and expensive, prevention of new alien species naturalizations and invasions should be a priority.

Many of the currently preventative risk assessments and legislation with regard to invasive alien organisms focus on avoiding the introduction of species with high invasion potential into a country (e.g. Pheloung et al. 1999; EU 2014). However, in the case of plants, thousands of alien species have already passed the introduction barrier as they are currently growing in public green spaces, botanical gardens, arboreta and private gardens. Botanical gardens in Europe alone are estimated to harbour $>80,000$ plant taxa (Heywood and Sharrock 2013), and the European Garden Flora (Cullen et al. 2011) lists $>20,000$ plant taxa as being regularly grown in European gardens. At least 783 of those alien species recorded in the European Garden Flora have already naturalized in other parts of the world (Dullinger et al. 2017). This implies that the garden flora constitutes an enormous pool of potential future invaders. For some of these species, the current environment already permits naturalization, but, due to long lag phases, they may simply need more time to spread (Kowarik 1995; Williamson et al. 2005). For other species, the current local environmental conditions in the areas where they are planted may have prevented them from naturalizing. Environmental conditions, however, will change rapidly under future climate warming (Dehnen-Schmutz 2011). Only a small proportion of alien garden plants are likely to escape cultivation and become invasive, and to prevent this we need tools to predict which species have the potential to establish and spread under current and future climatic conditions.

It is notoriously difficult to predict the invasion potential of species due to the context specificity of 
invasion events (Kueffer et al. 2013; van Kleunen et al. 2015a; Woodford et al. 2016). Nevertheless, several factors are almost universally associated with naturalization and/or invasion success. First, propagule pressure increases the likelihood of establishment (Lockwood et al. 2005). For garden plants, propagule pressure can be quantified as the number of gardens a species has been planted in (Hanspach et al. 2008; Bucharová and van Kleunen 2009; Maurel et al. 2016) and the number of individuals per garden. Second, although a few plant species have become invasive in regions that are outside their native climatic envelope following a shift of their climatic niche (e.g. Broennimann et al. 2007), climatic suitability is in most cases positively related to naturalization success (e.g. Feng et al. 2016). Third, species are more likely to naturalize and become invasive in a given region when they have a history of naturalization or invasion elsewhere (e.g. Daehler and Strong 1993; Reichard 1996; Pyšek et al. 2003). Planting frequency, climatic suitability and global naturalization success thus bear promise for developing simple tools to screen garden plants for their local naturalization potential. These tools could allow city authorities to produce a list of alien species grown in the public and private gardens that might pose significant naturalization risks and should either be removed or put on a watch list.

Here, we used the garden flora of Radolfzell, a small city in southern Germany, to investigate whether naturalization success of garden plants is associated with their current planting frequency, climatic suitability and known naturalization status somewhere in the world. We first inventoried the garden-plant species and estimated their planting frequency in the public green spaces and private gardens of the city. We then combined this with other data on naturalization in the city and its immediate vicinity, in the entire country of Germany and globally. In addition, we used climatic niche modelling based on known occurrences elsewhere in the world to assess climatic suitability under the current climate and under climates projected for 2050 and 2070. Based on these analyses, we defined empirically-assessed local naturalization thresholds to predict which species have the potential to naturalize in Radolfzell under forecasted future climatic conditions.

\section{Methods}

Ornamental garden-plant inventory

Data for the ornamental garden-plant-species inventory were collected by the first author in AugustNovember 2014 and in April-August 2015 in the city of Radolfzell $\left(47.7452^{\circ} \mathrm{N}, 8.9669^{\circ} \mathrm{E}\right)$, Germany. Radolfzell is situated at the western shore of Lake Constance close $(\sim 5 \mathrm{~km})$ to the border with Switzerland. It covers an area of $\sim 59 \mathrm{~km}^{2}$, and has a human population of $\sim 30,000$. In total, a sample of 111 garden sites, ranging in size from $\sim 1$ to $\sim 175,000 \mathrm{~m}^{2}$, were inventoried, of which 50 are managed by the city (i.e. are public green spaces) and 61 by private persons (private plantings). Public green spaces included public parks $(\mathrm{n}=11)$, roundabouts $(\mathrm{n}=9)$, boulevards $(\mathrm{n}=2)$, planted road sides $(\mathrm{n}=8)$, planters (i.e. large plant containers; $\mathrm{n}=5)$, public plantings in residential areas $(n=14)$ and nursery stocks $(n=1)$. Private plantings included home gardens, both front yards and backyards $(\mathrm{n}=56)$, and private plantings on graveyards $(\mathrm{n}=5)$. To make the garden-plant inventory as comprehensive as possible, we focused on home gardens which the owners regularly entered into garden contests, as we expected a larger assortment of plants in these gardens than in the gardens of mainstream gardeners that we inventoried.

In each garden, all ornamental garden plants were recorded and identified to the (infra)species level with the help of private-garden owners and the city gardeners, and also by using nursery catalogues (Lappen 2009; Pflanzen Bruns 2013). Taxon names were standardized with The Plant List (version 1.1; http://www.theplantlist.org/) using the "taxonstand" package (version 2.0; Cayuela et al. 2017) and R 3.2.1 ( $\mathrm{R}$ Core Team 2014). This allowed us to correct spelling mistakes and to get accepted taxon names in the case of synonyms, and facilitated adding information on naturalization of the species (see below). Cultivars were, if possible, assigned to the species from which they were derived. Cultivars and other taxa that could not be assigned to species $(n=44)$ were removed from the data set. For species that we did not find in The Plant List, we kept the original names.

It was not feasible to exactly count the number of plants per species in each garden, particularly not for 
clonal species in which individuals are difficult to distinguish. Therefore, when a species occurred in a garden, we assigned it to one of three abundance classes by estimating the number of plants: (1) 1-3 plants (shoots in the case of clonal plants), (2) 4-99 plants and (3) > 99 plants. For each garden-plant species, we assessed whether or not it is native to Germany (FloraWeb; http://www.floraweb.de/). For all alien species, we collected data on life form (herb, vine, shrub, tree, aquatic plant) and life span (annual, biennial, perennial) from nursery catalogues (Lappen 2009; Pflanzen Bruns 2013) and the European Garden Flora (Cullen et al. 2011). In addition, we used the Kew World Checklist of Selected Families (http:// apps.kew.org/wcsp/home.do) and GRIN-Global (https://npgsweb.ars-grin.gov), as well as additional internet searches, to determine which continent of the Taxonomic Databases Working Group (TDWG) scheme (Brummit 2001) the species are native to.

Local, national and global naturalization status

For each of the recorded alien garden-plant species in the city of Radolfzell, we assessed (1) whether it is known to be naturalized somewhere in the world, (2) whether it is naturalized somewhere in Germany and (3) whether it is has been reported from the wild in Radolfzell or its surroundings. To determine whether a species is naturalized somewhere in the world, we checked the species' presence in the Global Naturalized Alien Flora (GloNAF) database (version 1.1; van Kleunen et al. 2015b). The GloNAF database contains lists of naturalized alien species for 843 regions (countries, states, provinces, islands), covering $\sim 83 \%$ of the global land surface (van Kleunen et al. 2015b). For each species, we extracted the number of GloNAF regions in which it is known to be naturalized as a measure of its global naturalization extent (e.g. Razanajatovo et al. 2016). Secondly, we used the German FloraWeb database (http://www. floraweb.de) to assess whether a species has been found in the wild (i.e. outside of cultivation) (1) somewhere in Germany and (2) in the two TK25 grid cells (each $10^{\prime}$ longitude $\times 6^{\prime}$ latitude; c. $133 \mathrm{~km}^{2}$ ) of the plant distribution maps in which the city of Radolfzell lies. A species was considered to be naturalized somewhere in Germany when FloraWeb explicitly classified it as a naturalized neophyte ("eingebürgerter Neophyt") in the main description of the species or when it was classified as such in at least one of the 11,956 quarter-TK25 grid cells of the species' distribution map. The distribution maps in FloraWeb (or FloraKart) are from the German plant distribution atlas (Netzwerk Phytodiversität Deutschland \& Bundesamt für Naturschutz 2013), which aggregated and harmonized the data (mostly collected by volunteers) from the different floristic mapping schemes of German federal states, societies and private persons. The distribution maps indicate whether the last record of a species in a grid cell was post 1980, $1950-1980$ or pre 1950 . However, as most records are post 1980 , we did not consider the different time periods in our analyses.

Climatic niche modelling

Current and projected future climatic suitability of the introduced ornamental species in Radolfzell were assessed using the niche-based species-distribution modelling platform BIOMOD (Thuiller et al. 2009). Data on species-presence locations were downloaded from the Global Biodiversity Information Facility (GBIF; http://www.gbif.org/) using the R package "rgbif" (Chamberlain et al. 2015). Although GBIF contains errors and biases (Meyer et al. 2016), which can affect the results of climatic-niche modelling, it is the most comprehensive database on global distributions of species. After removing invalid and clearly errant presence points, such as those falling in oceans and Antarctica, and removing species with insufficient data ( $<40$ occurrence records; Dellinger et al. 2016), climatic niche modelling, as in Dullinger et al. (2017), could be done for 670 of the 954 alien garden-plant species in our inventory. To avoid that climatic suitability values would be biased upward due to circularity for species with GBIF records in Radolfzell, we did not consider GBIF presence points in Radolfzell and its immediate surroundings (see below) for the climatic niche modelling.

Mean bioclimatic variables for 1950-2000 were extracted at $10^{\prime}$ resolution from WorldClim (Hijmans et al. 2005; www.worldclim.org). We used six of the 19 bioclimatic variables in WorldClim: (1) BIO4: temperature seasonality, (2) BIO5: maximum temperature of the warmest month, (3) BIO6: minimum temperature of the coldest month, (4) BIO15: precipitation seasonality, (5) BIO16: precipitation of the wettest quarter and (6) BIO17: precipitation of the 
driest quarter. These variables were selected because they are known to affect plant-species distributions (Root et al. 2003). In addition, these variables have pairwise Pearson's $\mathrm{r}$ values below 0.75 (Dullinger et al. 2017). This is slightly higher than the threshold recommended by Dormann et al. (2013), and therefore small effects of multicollinearity on model outcomes cannot be fully excluded.

Climatic niche models were built on a global climate background, excluding the $\sim 690 \mathrm{~km}^{2}$ area encompassing the city of Radolfzell (i.e., the area within the rectangle formed by the coordinates $47.85^{\circ} \mathrm{N}$ and $8.80^{\circ} \mathrm{E}, 47.65^{\circ} \mathrm{N}$ and $8.80^{\circ} \mathrm{E}, 47.65^{\circ} \mathrm{N}$ and $9.20^{\circ} \mathrm{E}$, and $47.85^{\circ} \mathrm{N}$ and $9.20^{\circ} \mathrm{E}$ ) on which we would ultimately project these models. For future model projections onto Radolfzell, we extracted current and projected future bioclimatic data from WorldClim for that same previously excluded area. To test how climatic suitability of species might change under a severe, but still realistic, climate-change scenario, we chose the RCP 8.5 scenario (a scenario based on high greenhouse gas emissions; IPCC 2013). Based on this scenario, projections of the bioclimatic data for the years 2050 and 2070 were calculated as the average of the projections of the ACCESS1-0 and MIROC5 models.

To decrease uncertainty, ensemble climatic niche models were built combining four separate algorithms: two regression-based [generalized linear modeling (GLM), generalized additive modeling (GAM)] and two machine-learning based [random forest (RF) and generalized boosted modelling (GBM)] algorithms. Models were built using the biomod function of the "biomod2" package (Thuiller et al. 2016) in R 3.2.4 (R Core Team 2016). As these algorithms require presence and absence data, we acquired presence data from GBIF and created random pseudo-absences for each taxon outside Radolfzell. For the creation of pseudo-absences for the different modelling algorithms, we followed the recommendations of BarbetMassin et al. (2012; also see Dullinger et al. 2017; Klonner et al. 2017). Pseudo-absences were randomly selected within a radius of 100 ten-min cells around the presence points. For the two regression-based models, three sets of 10,000 pseudo-absences were generated for separate modeling. However, as recommended by Maggini et al. (2006), the absences were weighted to assure that the prevalence (i.e. frequency of species' occurrences in the data set) was 0.5 . For the machine-based models, we also generated three sets of pseudo-absences, but here the number of pseudoabsences was set equal to the number of presence points used for each taxon (i.e. the prevalence was $0.5)$.

For model evaluation, datasets were randomly split with $80 \%$ of presence and pseudo-absence data used for model calibration, and $20 \%$ used for subsequent evaluation. This random split was performed three times for the regression-based model datasets and the machine-based model datasets. For each species, the four model types with three sets of pseudo-absences and three data splits each resulted in 36 individual models. The regression-based and machine-learningbased models were then separately combined into two individual ensemble forecasts to generate climaticsuitability projections. Poor models (TSS $<0.7$; Allouche et al. 2006) were excluded from the ensemble forecasts, and the others were weighted according to their TSS score.

Ensemble forecasts were then projected onto the city of Radolfzell and the surrounding $\sim 690 \mathrm{~km}^{2}$ for current climatic conditions (annual mean temperature: $9.2^{\circ} \mathrm{C}$ ), as well as projected climatic conditions in $2050\left(12.8^{\circ} \mathrm{C}\right)$ and $2070\left(14.0^{\circ} \mathrm{C}\right.$; see Table S1 for current and projected bioclimatic variables). As the spatial resolution of the climatic data $\left(10^{\prime} \times 10^{\prime}\right.$ grid cells) does not fully match the resolution of the FloraWeb distribution maps in Germany $\left(10^{\prime} 6^{\prime}\right.$ grid cells), the area used for the climatic projections of Radolfzell is larger than the area used to determine which of the naturalized plants have already been recorded in the Radolfzell area. For each projected time point, the minimum (i.e. more conservative) projection of climatic suitability was taken from an overlay of the two ensemble projections. For each species and time point, the mean climatic suitability probability across the two grid cells in which Radolfzell lies was calculated as the probabilistic output of the ensemble forecasts. When for a species the current or future climate in Radolfzell falls outside the climatic range used for model calibration, forecasts could be unreliable. However, as Radolfzell has a temperate climate, it is unlikely that this was the case for the majority of the species for which we did climatic-niche modelling. 
Statistical analyses of naturalization success

To test how current naturalization success of the alien garden-plant species in Radolfzell relates to current planting frequencies in public and private gardens (number of gardens and the median of the abundance class across the gardens in which the species occurs), current climatic suitability and global naturalization frequency, we used generalized linear models with a binomial error distribution with the complementary $\log -\log$ link function. All explanatory variables were centred to a mean of zero and scaled to a standard deviation of one to facilitate interpretation of the estimates (Schielzeth 2010). Correlations between the explanatory variables were all below 0.55 , indicating only mild collinearity. The strongest correlations were between the frequency and abundance in public gardens $(r=0.54)$ and between the frequency and abundance in private gardens $(r=0.35)$. When we excluded abundances in public and private gardens, the results remained qualitatively the same. These analyses were done using the glm function implemented in the standard statistics package of $\mathrm{R}$ ( $\mathrm{R}$ Core Team 2016).

\section{Results}

We identified a total of 1268 ornamental garden-plant species in the public green spaces and private gardens of Radolfzell. Of these, 954 (75\%) were alien to Germany, among them 462 were found in public green spaces and 775 in private gardens (283 species were found in both). The largest donor region of the alien garden-plant species was temperate Asia, followed by North America and Europe (Fig. 1). The alien garden flora of Radolfzell covered 127 families, the most highly represented being Asteraceae (i.e. Compositae in The Plant List) with 116 species, Rosaceae with 65 species and Lamiaceae with 50 species (Fig. S1). Most of the introduced garden plants were perennial herbs (506 species) and shrubs (210 species; Fig. S2).

Current naturalization success of garden-plant species

Out of the 954 alien garden-plant species, 627 (66\%) are known to be naturalized somewhere in the world, $168(18 \%)$ have naturalized somewhere in Germany, and 48 (5\%) have been recorded in the wild in Radolfzell (i.e. the two grid cells in which Radolfzell lies). Among the 670 species for which we could assess climatic suitability (i.e. species with $>40$ occurrences in GBIF), their occurrence in the wild in Radolfzell was not significantly related to their current planting frequency in public green spaces and private gardens (Table 1). However, local naturalization success was significantly positively related to current climatic suitability and to the number of global regions where a species is naturalized (Table 1; Fig. 2). All locally naturalized species had a climatic suitability probability of 0.75 or higher (median $=0.97$ ), compared to a median of 0.69 for the non-naturalized species, and are naturalized in 13 or more regions around the globe $($ median $=61)$, compared to a median of 9 for the non-naturalized ones.

Potential future naturalization success of gardenplant species

Based on the climate projections of the RCP 8.5 scenario that projects a regional increase in mean annual temperature of $3.6^{\circ}-4.8^{\circ}$ for Radolfzell for the mid-twenty-first century, the median climatic suitability probability of the garden-plant species in the city of Radolfzell is projected to decrease from current 0.76 to 0.45 in 2050, and to 0.18 in 2070 (Fig. 2). For 39 out of 48 species that are currently locally naturalized, the climatic suitability probability in 2050 will be below the current probability threshold of 0.75 . In 2070, all but two (Acer negundo and Parthenocissus quinquefolia) of the currently naturalized species will be below that threshold (Fig. 2).

Although for the majority of garden-plant species, the climatic suitability will decrease, it will increase for 219 species (out of 670 species with climatic suitability data) by 2050 and 171 species by 2070 . Of the species that are naturalized in $\geq 13$ regions around the world (i.e. above the global naturalization threshold for the currently locally naturalized species), 42 species will increase their climatic suitability probability above the current 0.75 threshold by 2050 , and 23 species will do so by 2070 . This results in a list of 45 garden species that are likely to naturalize given a projected increasing climatic suitability by 2050 and/ or 2070 (Table 2). 
Fig. 1 Origins of the 954 alien garden-plant species grown in public green spaces and private gardens of the city of Radolfzell, Germany. The regions of origin used are the biogeographically defined continents recognized by the Biodiversity Information Standards (also known as the Taxonomic Databases Working Group or TDWG; Brummit 2001). "Cultivated only" refers to species that are only known from cultivation. Note that the sum of the number of species per origin is larger than 954 , because many species are native to multiple continents

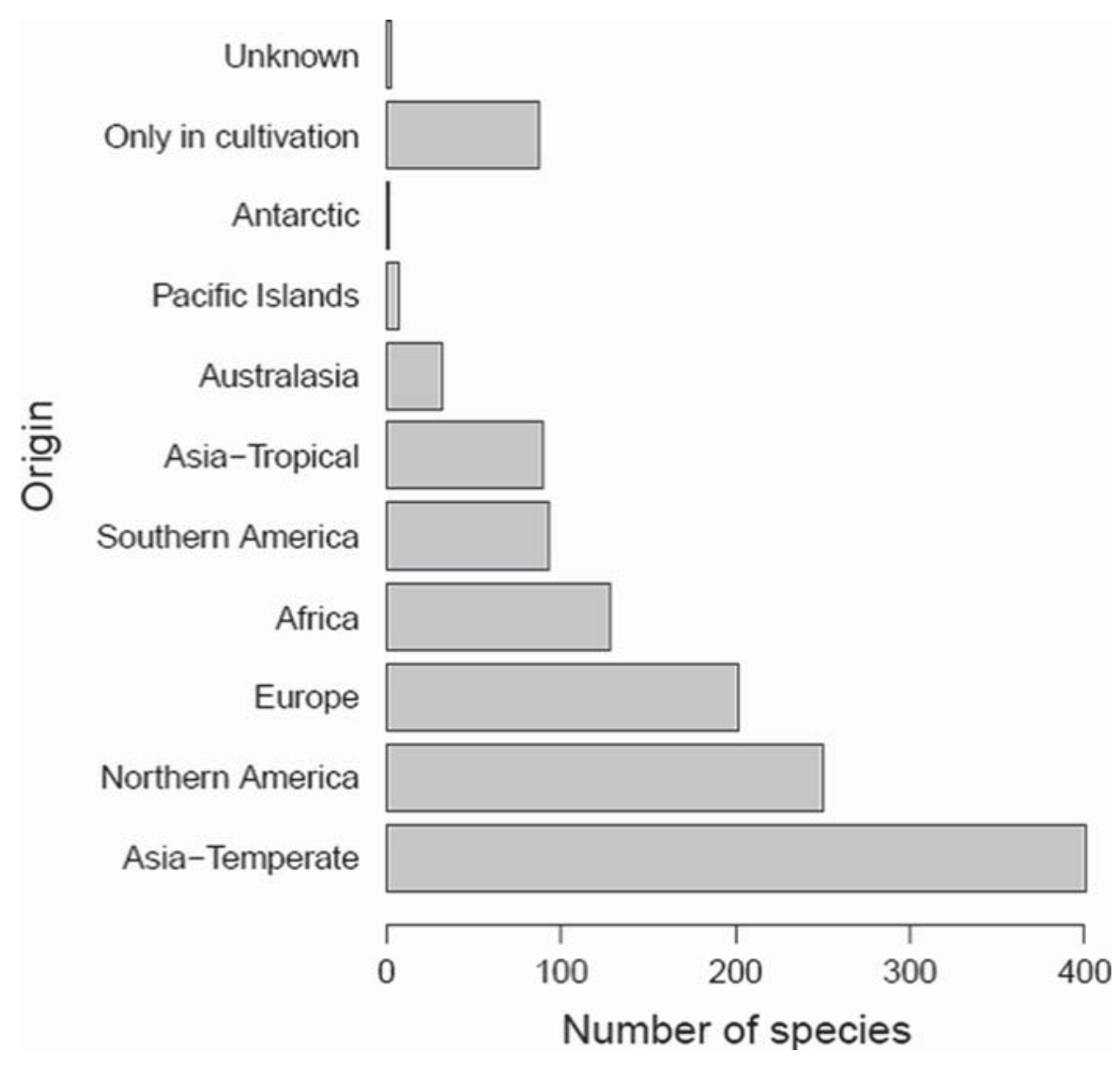

Table 1 Results of binomial GLMs testing how naturalization in Radolfzell (yes, no) depends on global naturalization frequency, climatic suitability and planting frequencies and abundances in private and public gardens

\begin{tabular}{lrrr}
\hline & Estimate $( \pm \mathrm{SE})$ & z-value & $P$ \\
\hline Intercept & $-13.992(2.614)$ & -5.35 & $<0.001$ \\
Global naturalization frequency $^{\mathrm{a}}$ & $2.374(0.354)$ & 6.70 & $<0.001$ \\
Climatic suitability & $10.148(2.553)$ & 3.98 & $<0.001$ \\
No. private gardens & $-0.077(0.145)$ & -0.54 & 0.593 \\
No. public gardens & $-0.008(0.166)$ & -0.05 & 0.962 \\
Abundance private garden & $-0.150(0.176)$ & -0.85 & 0.394 \\
Abundance public garden & $0.219(0.191)$ & 1.15 & 0.251 \\
\hline
\end{tabular}

All explanatory variables were centred to a mean of zero and scaled to a standard deviation of one

${ }^{\mathrm{a}}$ Naturalization frequency was $\ln$-transformed after adding 1 to the number of GloNAF regions in which the species is naturalized

\section{Discussion}

Based on a comprehensive inventory of ornamental garden plants grown in public green spaces and private gardens of the city of Radolfzell, we show that more than three quarters of the garden-plant species are alien and that two-thirds of those are already known to be naturalized somewhere in the world. In other words, most of the currently planted alien garden species have proven their ability to naturalize. Indeed, we found that a considerable number of these garden plants were already naturalized in Radolfzell or in 


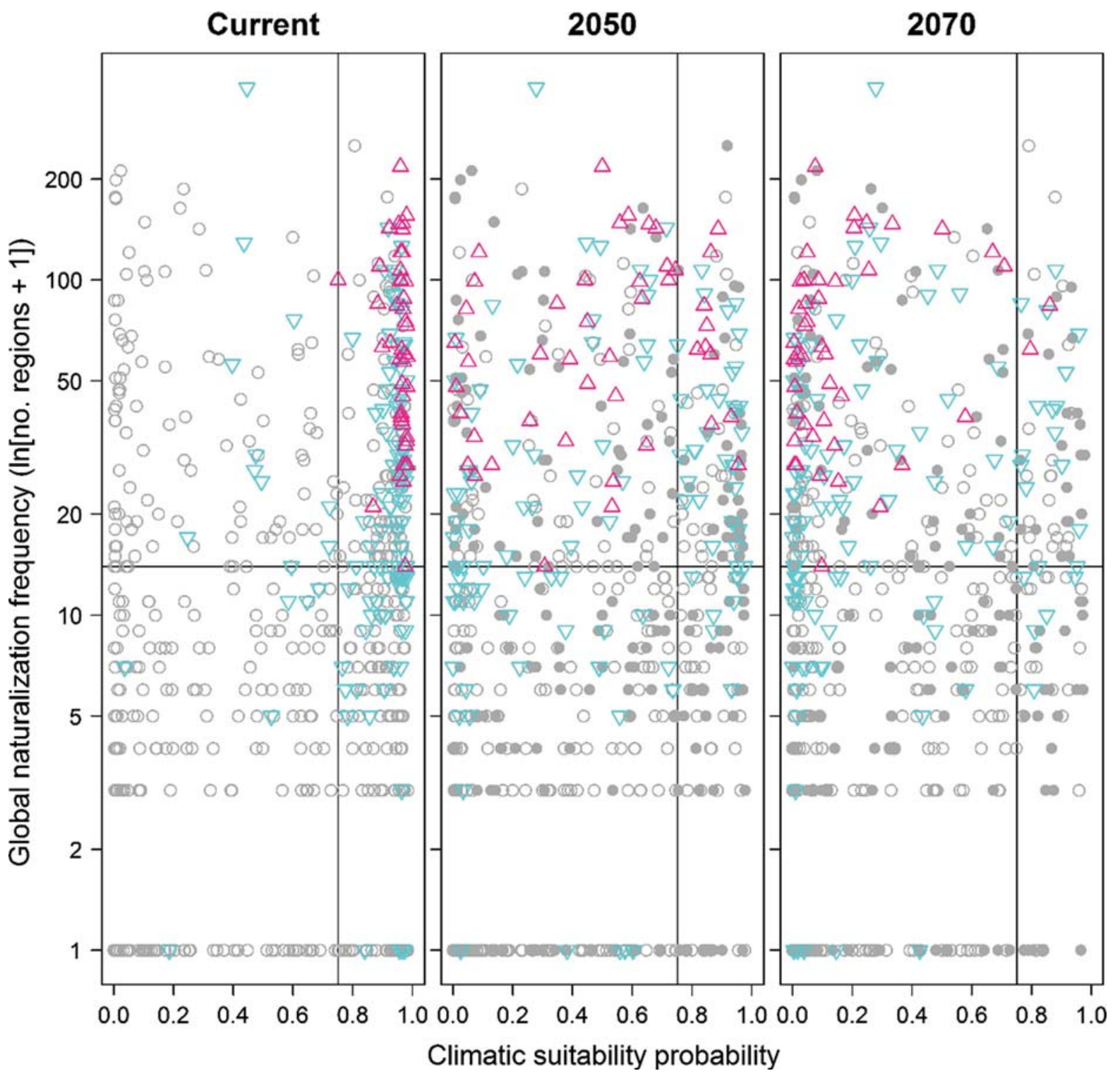

Fig. 2 Current and projected future climatic suitability probabilities under severe climate change (RCP 8.5; IPCC 2013) and global naturalization frequencies (number of GloNAF regions; van Kleunen et al. 2015b) of alien garden-plant species grown in Radolfzell. Shown are the 670 species with sufficient data for climatic niche modelling. Species that are currently naturalized in Radolfzell are indicated with pink upwards pointing triangles, species that are currently naturalized in other parts of Germany

other parts of Germany. The species that are currently naturalized in Radolfzell are distinguished from most of the non-naturalized ones by having the highest climatic suitability probabilities $(\geq 0.75)$ and by being naturalized in at least 13 out of 843 regions worldwide. are indicated with cyan downwards pointing triangles, and species not naturalized in Germany are indicated with grey circles. For the 2050 and 2070 projections, non-naturalized taxa with an increased climatic suitability relative to their current one have filled circles. The vertical and horizontal black lines indicate the climatic suitability probability $(0.75)$ and the global naturalization frequency ( 13 regions), respectively, exceeded by all ornamental plants currently naturalized in Radolfzell

When using these two values as thresholds also for naturalization in Radolfzell under projected climates in the years 2050 and 2070, we identified 45 species that are not naturalized now but are highly likely to become naturalized in the future. 
Table 2 Proposed Watch List of 45 alien species currently planted in public and/or private gardens of the city of Radolfzell, Germany

\begin{tabular}{|c|c|c|c|}
\hline \multirow[t]{2}{*}{ Species } & \multirow[t]{2}{*}{ Naturalized in other parts of Germany } & \multicolumn{2}{|c|}{ Predicted to pass climatic suitability threshold } \\
\hline & & In 2050 & In 2070 \\
\hline Glandularia canadensis & No & No & Yes \\
\hline Helenium amarum & No & No & Yes \\
\hline Phyla nodiflora & No & No & Yes \\
\hline Albizia julibrissin ${ }^{\mathrm{a}}$ & No & Yes & Yes \\
\hline Campsis radicans & No & Yes & Yes \\
\hline Coreopsis grandiflora & No & Yes & Yes \\
\hline Coreopsis lanceolata & No & Yes & Yes \\
\hline Coreopsis tinctoria & No & Yes & Yes \\
\hline Elaeagnus pungens ${ }^{\mathrm{a}}$ & No & Yes & Yes \\
\hline Exochorda racemosa & No & Yes & Yes \\
\hline Gaillardia pulchella & No & Yes & Yes \\
\hline Gaura lindheimeri & No & Yes & Yes \\
\hline Gleditsia triacanthos $^{\mathrm{a}}$ & Yes & Yes & Yes \\
\hline Nandina domestica ${ }^{\mathrm{a}}$ & No & Yes & Yes \\
\hline Philadelphus inodorus & No & Yes & Yes \\
\hline Pontederia cordata & No & Yes & Yes \\
\hline Pyracantha koidzumii ${ }^{\mathrm{a}}$ & No & Yes & Yes \\
\hline Spiraea prunifolia & No & Yes & Yes \\
\hline Taxodium distichum & Yes & Yes & Yes \\
\hline Tradescantia virginiana & No & Yes & Yes \\
\hline Vitex agnus-castus ${ }^{\mathrm{a}}$ & No & Yes & Yes \\
\hline Wisteria sinensis & No & Yes & Yes \\
\hline Yucca gloriosa & No & Yes & Yes \\
\hline Acer palmatum & No & Yes & No \\
\hline Akebia quinata ${ }^{\mathrm{a}}$ & No & Yes & No \\
\hline Amorpha fruticosa $a^{\mathrm{a}}$ & Yes & Yes & No \\
\hline Aисиbа japonica & No & Yes & No \\
\hline Celastrus orbiculatus $^{\mathrm{a}}$ & Yes & Yes & No \\
\hline Cosmos sulphureus & No & Yes & No \\
\hline Cryptomeria japonica $^{\mathrm{a}}$ & No & Yes & No \\
\hline Euonymus alatus $^{\mathrm{a}}$ & No & Yes & No \\
\hline Malcolmia maritima & No & Yes & No \\
\hline Mirabilis jalapa & No & Yes & No \\
\hline Miscanthus sacchariflorus & Yes & Yes & No \\
\hline Origanum majorana & No & Yes & No \\
\hline Parthenocissus tricuspidata & Yes & Yes & No \\
\hline Paulownia tomentosa ${ }^{\mathrm{a}}$ & Yes & Yes & No \\
\hline Pennisetum alopecuroides & No & Yes & No \\
\hline Physostegia virginiana & No & Yes & No \\
\hline Platanus acerifolia & No & Yes & No \\
\hline Punica granatum ${ }^{\mathrm{a}}$ & No & Yes & No \\
\hline Salix babylonica $^{\mathrm{a}}$ & Yes & Yes & No \\
\hline Salvia splendens & No & Yes & No \\
\hline
\end{tabular}


Table 2 continued

\begin{tabular}{llll}
\hline Species & Naturalized in other parts of Germany & \multicolumn{2}{l}{ Predicted to pass climatic suitability threshold } \\
\cline { 3 - 4 } & & In 2050 & In 2070 \\
\hline Spiraea thunbergii & No & Yes & No \\
Wisteria floribunda $^{\text {a }}$ & No & Yes & No \\
\hline
\end{tabular}

These species are not locally naturalized yet, but are globally naturalized in 13 or more regions and likely to pass the current climaticsuitability-probability threshold of 0.75 in 2050 and/or 2070. Five of the species are currently already naturalized in other parts of Germany

${ }^{a}$ Species known to be considered invasive somewhere in the world based on data from Weber (2003, and unpublished update for second edition), Rejmánek and Richardson (2013), CABI Invasive Species Compendium (http://www.cabi.org/isc/) and the Invasive Species Specialist Group ISSG (http://www.issg.org/)

Current naturalization success of garden-plant species

We found that $48(5 \%)$ and $168(18 \%)$ of the 954 alien garden-plant species in Radolfzell are already naturalized in Radolfzell and Germany, respectively. This means that more than $30 \%$ of the 156 recorded naturalized plants in Radolfzell and more than $35 \%$ of the 479 naturalized plants in Germany (http:// floraweb.de/) are currently grown as ornamentals in the gardens of Radolfzell. Some of these naturalized species, like Cymbalaria muralis, may not have been planted but have spontaneously established themselves in the gardens. Such species are frequently tolerated by gardeners because of their ornamental value. However, most of the naturalized alien gardenplant species have been planted intentionally by city authorities and/or private gardeners. Almost twothirds $(627$ or $66 \%)$ of the 954 alien garden-plant species in Radolfzell are known to be naturalized somewhere in the world, which proves their naturalization ability. Ninety-nine ( $\sim 10 \%)$ of these species are even considered to be invasive somewhere in the world (see Supplementary material 2), because they have negative impacts on native species or economy (CBD 2000), and 50 of them show a higher climatic suitability probability than the current threshold of 0.75 (Supplementary material 2). This indicates that many of the species that are planted in Radolfzell and not locally naturalized yet, have nevertheless a high potential to naturalize and become invasive under current climate conditions.

Propagule pressure or planting frequency is among the most consistent explanatory variables of local naturalization and invasion success (e.g. Daehler and
Strong 1993; Feng et al. 2016; Maurel et al. 2016). In our study, current planting frequency was not significantly related to naturalization. This could be because our estimates of the current planting frequencies were quite coarse. More importantly, current naturalization success is most likely driven by past planting frequencies, which might deviate from the current one (Dehnen-Schmutz et al. 2007). This implies that species planted more frequently now might have a higher likelihood of naturalizing in the future (Essl et al. 2010).

Remarkably, garden-plant species naturalized in Radolfzell distinguish them from most other gardenplant species by being naturalized in many $(\geq 13)$ regions around the world and having a high climatic suitability probability ( $\geq 0.75$; Fig. 2 ). Nevertheless, there were 140 introduced garden-plant species that also occur in $\geq 13$ regions and have a climatic suitability probability $\geq 0.75$, and that have not been recorded as naturalized in Radolfzell yet. Thus, based on our naturalization thresholds, these species would be falsely classified as naturalized. Such false positives are very common in risk assessments, but models have nevertheless shown that risk assessment may pay off in the long term (Keller et al. 2007). Sixty-four of the 140 false positives are species known to be naturalized in other parts of Germany already, and six are naturalized in neighbouring Switzerland (Wittenberg 2005). These species might simply not have been recorded as naturalized in Radolfzell yet even if they are. Still, this leaves many species that based on the climatic suitability and global naturalization thresholds could naturalize in Radolfzell but have not done so in Germany or Switzerland yet. So, despite the overall strong separation between naturalized and 
non-naturalized species (Fig. 2), the number of false positives based on our two thresholds is still high. This could reflect that certain components of habitat suitability (e.g. edaphic factors, disturbance levels, biotic interactions) that were not included in the species distribution modelling are not optimal for these species (see also Guisan and Thuiller 2005). It could also reflect that some of these species are only represented by cultivars that might be infertile or have a lower competitive ability or climatic suitability than the wildtype used for the climatic niche modelling. Furthermore, it could reflect that some of these species have been introduced only recently, and are still in their lag phase (e.g. Kowarik 1995; Williamson et al. 2005). Lag phases are likely to be longer for woody species than for herbaceous ones, as species with longer generation times usually have longer lag times (Kowarik 1995). Although a post hoc test showed a trend that woody species were indeed slightly overrepresented among the false positives, this difference was not significant (Supplementary Results 1). Differences in continent of origin were also not significant (Supplementary Results 1). Whatever the exact reason for why these species have not established yet, they have proven naturalization potential, and should be monitored for any signs of potential spontaneous establishment in Radolfzell and its surroundings.

Potential future naturalization success of gardenplant species

The modelling of climatic suitability, and consequently predicting future naturalization success, is restricted to species with sufficient distribution data. This means that we had to exclude $30 \%$ (284 out of 954) of alien garden-plant species from our analysis because of lack of data in GBIF. In future studies, this number could be reduced by searching for distribution data that is not aggregated by GBIF yet. It is also likely that with the ongoing addition of occurrence data to GBIF, distribution data will become less limiting and less geographically biased (Meyer et al. 2016). Although 30\% appears high, it is likely that most of the species with insufficient distribution data are relatively rare species with low naturalization ability. Indeed, in our study, distribution data were particularly likely to be missing for species that are not naturalized in Radolfzell, and also not naturalized in the rest of Germany or the rest of the world (Table S2).
In other words, the climatic suitability analysis is biased in favour of species with high naturalization ability.

Based on the RCP 8.5 scenario, temperatures are projected to increase considerably $\left(3.6^{\circ}-4.8^{\circ}\right)$ and precipitations will slightly $(83-121 \mathrm{~mm})$ increase by the years 2050 and 2070 in Radolfzell (Table S1). As a result, climatic suitability is projected to have declined by the years 2050 and 2070 for most of the currently grown garden-plant species (Fig. 2). This probably reflects that an important criterion for selecting a garden plant is that its environmental requirements allow it to be grown at the specific location (Kendal et al. 2012). Most likely if we would have chosen a less severe climate-change scenario, fewer species would have projected declines in climatic suitability and more species might have increased climatic suitability.

Despite a preference for growing climatically suited species, many species from continents with warmer climates (Fig. 1) are currently grown in the gardens of Radolfzell. These species are either frequently replaced or protected in winter against frost. Such species are likely to benefit from climate warming in the future, particularly when precipitation will also slightly increase. By the years 2050 and 2070, respectively 33 and $26 \%$ of the species are likely to have an increased climatic suitability. Among these species, 45 are already widely naturalized in other parts of the world and would achieve a climatic suitability probability similar to the values of the currently naturalized species (Table 2). If the thresholds separating naturalised and non-naturalised species identified under the current climate do not change with climate change, these garden-plant species are likely to constitute the next generation of naturalized plants in Radolfzell. Fifteen of these species are not only widely naturalized but are also invasive in other parts of the world, i.e. have spread rapidly, often forming dense populations and thus have often negatively affected native biodiversity (Table 2). Although there will also be false positives among these species, they should be monitored with priority for spontaneous establishment inside and outside the gardens of the city. 
Challenges and recommendations

Ecologists have been searching for predictors of alien plant establishment and spread since the seminal work by Baker (1965). In recent years, the availability of global data sets on naturalized (van Kleunen et al. 2015b), weedy (Randall 2012) and invasive plant species (Weber 2003; Rejmánek and Richardson 2013; Turbelin et al. 2017), and global species occurrence data (http://www.gbif.org/) has increased. This is complemented by substantial advances in modelling methods and software (e.g. Thuiller et al. 2009, 2016). This progress can now be employed to identify species with high naturalization and invasion potential that deserve particular attention (e.g. by putting them on watch lists; Dehnen-Schmutz 2011; Pergl et al. 2016b).

While in principle the methods used in this study may be readily reproducible for almost any city or municipality, the climatic niche modelling is the most methodologically and data demanding part of our approach. As an alternative, we also tried to identify potential invaders based on similarities between the mean annual temperature in Radolfzell and the median mean annual temperature in the regions where these species are naturalized according to the GloNAF database (van Kleunen et al. 2015b). This much simpler method is obviously restricted to species that have already shown naturalization ability in other regions and does not account for species distribution or mean annual temperature variation within and among GloNAF regions. Despite these limitations, the alien garden-plant species that are already naturalized in Radolfzell and Germany had a median mean annual temperature of the GloNAF regions that was closer to the mean annual temperature in Radolfzell, than was the case for non-naturalized species (Figs. S3 and S4). In other words, the alien garden-plant species naturalized in Radolfzell are also naturalized in other regions of the world with a mean temperature similar to the one in Radolfzell. So, although climatic niche modelling should certainly be the method of choice, comparing the local climate to the climate in regions where the species has naturalized already gives at least a reasonably reliable indication of which species have naturalization potential.

A prerequisite for applying either method is that the cities inventory species grown in their public and private green spaces. Monitoring as well as identifying species that have already been planted, particularly in the case of horticultural cultivars, might be challenging and costly (Pergl et al. 2016a). For new plant material, species information is usually provided by the nursery, but here one has to be aware of mislabelling (e.g. Thum et al. 2012). We made the inventory over 2 years, and spent $\sim 350$ working hours to visit the 111 garden sites and identify the species, in the relatively small city of Radolfzell. For large cities, this will of course be much more laborious. However, this investment may pay off in the future when it prevents the costs of further biological invasions. Ideally, neighbouring cities would exchange inventories and collaborate in developing strategies to avoid that species invade from their own gardens or the gardens of the neighbouring city. National legislation should be developed to coordinate such an effort. It is also critical to collaborate with gardeners and environmental agencies to communicate results and planting recommendations in such a way that is useful to them.

Our approach cannot replace a full risk assessment, which should also include information on plant traits related to reproduction and dispersal and possible negative impacts of the species assessed (e.g. Pheloung et al. 1999). Nevertheless, we have shown that our approach is well-suited and applicable as one element of a screening or horizon scanning-type approach. This is something that can also be done at smaller (e.g. botanical gardens) and larger spatial scales (e.g. countries).

Acknowledgements We thank our collaborators at the Deutsche Umwelthilfe (DUH), Tobias Herbst and Robert Spreter, and Mario Jost and all other gardeners who assisted in species identification. We thank Ewald Weber for providing his unpublished list of invasive plant species of the world. This research was funded by the Klimopass Programm of the Landesanstalt für Umwelt, Messungen und Naturschutz, Baden-Württemberg (Project No. 4500347101/23 to the DUH and MvK), the German Research Foundation (DFG, Project No. KL1866-9/1), and the ERA-Net BiodivERsA, with the national funders ANR (French National Research Agency), DFG, and FWF (Austrian Science Fund), part of the 2012-2013 BiodivERsA call for research proposals. PP and JP were supported by Project No. 14-36079G Centre of Excellence PLADIAS (Czech Science Foundation), DG16P02M041 (NAKI II of the Ministry of Culture of the Czech Republic) and longterm research development project RVO 67985939 (The Czech Academy of Sciences). An early version of the paper was presented at a workshop on 'Non-native species in urban environments' hosted and funded by the DST-NRF Centre of Excellence for Invasion Biology (CIB) in Stellenbosch, South 
Africa, in November 2016. We appreciate the constructive advice provided by delegates at the workshop and two anonymous reviewers.

\section{References}

Allouche O, Tsoar A, Kadmon R (2006) Assessing the accuracy of species distribution models: prevalence, kappa and the true skill statistic (TSS). J Appl Ecol 43:1223-1232

Aronson MFJ, La Sorte FA, Nilon CH, Katti M, Goddard MA, Lepczyk CA, Warren PS, Williams NSG, Ciliers S, Clarkson B, Dobbs C, Dolan R, Hedblom M, Klotz S, Kooijmans JL, Kühn I, MacGregor-Fors I, McDonnell M, Mörtberg U, Pyšek P, Siebert S, Sushinsky J, Werner P, Winter M (2014) A global analysis of the impacts of urbanization on bird and plant diversity reveals key anthropogenic drivers. Proc R Soc B 281:20133330

Baker HG (1965) Characteristics and modes of origin of weeds. In: Baker HG, Stebbins GL (eds) The genetics of colonizing species. Academic Press, New York, pp 147-172

Barbet-Massin M, Jiguet F, Albert CH, Thuiller W (2012) Selecting pseudo-absences for species distribution models: how, where and how many? Methods Ecol Evol 3:327-338

Broennimann O, Treier UA, Müller-Schärer H, Thuiller W, Peterson AT, Guisan A (2007) Evidence of climatic niche shift during biological invasion. Ecol Lett 10:701-709

Brummit RK (2001) World geographical scheme for recording plant distributions, vol 2. Hunt Institute for Botanical Documentation, Pittsburgh

Bucharová A, van Kleunen M (2009) Introduction history and species characteristics partly explain naturalization success of North American woody species in Europe. J Ecol 87:230-238

Cayuela L, Stein A, Oksanen J (2017) Taxonstand: taxonomic standardization of plant species names. R package version 2.0. R Foundation for Statistical Computing. https:// CRAN.R-project.org/package $=$ Taxonstand

CBD (2000) Decision V/8. Alien species that threaten ecosystems, habitats or species. UNEP/CBD/COP/5/8. Secretariat of the Convention on Biological Diversity, Nairobi, Kenya

Chamberlain S, Ram K, Barve V, Mcglinn D (2015). rgbif: Interface to the Global Biodiversity Information Facility API. R package version 0.8.0. http://CRAN.R-project.org/ package $=$ rgbif

Clement EJ, Foster MC (1994) Alien plants of the British Isles. Botanical Society of the British Isles, London

Cullen J, Knees SG, Cubey HS (2011) The European garden flora: manual for the identification of plants cultivated in Europe, both out-of-doors and under glass, 2nd edn. Cambridge University Press, Cambridge

Daehler CC, Strong DR (1993) Predictions and biological invasions. Trends Ecol Evol 8:380

Dehnen-Schmutz K (2011) Determining non-invasiveness in ornamental plants to build green lists. J Appl Ecol 48:1374-1380

Dehnen-Schmutz K, Touza J, Perrings C, Williamson M (2007) The horticultural trade and ornamental plant invasions in Britain. Conserv Biol 21:224-231
Dellinger AS, Essl F, Hojsgaard D, Kirchheimer B, Klatt S, Dawson W, Pergl J, Pyšek P, van Kleunen M, Weber E, Winter M, Hörandl E, Dullinger S (2016) Niche dynamics of alien species do not differ among sexual and apomictic flowering plants. New Phytol 209:1313-1323

Dormann CF, Elith J, Bacher S, Buchmann C, Carl G, Carré G, Marquéz JRG, Gruber B, Lafourcade B, Leitão PJ, Münkemüller T, McClean C, Osborne PE, Reineking B, Schröder B, Skidmore AK, Zurell D, Lautenbach S (2013) Collinearity: a review of methods to deal with it and a simulation study evaluating their performance. Ecography 36:27-46

Dullinger I, Wessely J, Bossdorf O, Dawson W, Essl F, Gattringer A, Klonner G, Kuttner M, Moser D, Pergl J, Pyšek Thuiller W, van Kleunen M, Weigelt P, Winter M, Dullinger S (2017) Climate change will increase naturalization risk from garden plants in Europe. Glob Ecol Biogeogr 26:43-53

Essl F, Dullinger S, Rabitsch W, Hulme PE, Hülber K, Jarošík V, Kleinbauer I, Krausmann F, Kühn I, Nentwig W, Vilà Genovesi P, Gherardi F, Despres-Loustau M-L, Roques A, Pyšek P (2010) Socioeconomic legacy yields an invasion debt. PNAS 108:203-207

EU (2014) Regulation (EU) No. 1143/2014 of the European Parliament and of the Council of 22 October 2014 on the prevention and management of the introduction and spread of invasive alien species. Official Journal of the European Union L 317/35

Faulkner KT, Robertson MP, Rouget M, Wilson JRU (2016) Understanding and managing the introduction pathways of alien taxa: South Africa as a case study. Biol Invasions 18:73-87

Feng Y, Maurel N, Wang Z, Ning L, Yu F-H, van Kleunen M (2016) Introduction history, climatic suitability, native range size, species traits and their interactions explain establishment of Chinese woody species in Europe. Glob Ecol Biogeogr 25:1355-1366

Groves RH (1998) Recent incursions of weeds to Australia 1971-1995. CRC for Weed Management Systems technical series, vol 3. CRC for Weed Management Systems, Adelaide, pp 1-74

Guisan A, Thuiller W (2005) Predicting species distribution: offering more than simple habitat models. Ecol Lett 8:993-1009

Hanspach J, Kühn I, Pyšek P, Boos E, Klotz S (2008) Correlates of naturalization and occupancy of introduced ornamentals in Germany. Perspect Plant Ecol Evol Syst 10:241-250

Heywood VH, Sharrock S (2013) European code of conduct for botanic gardens on invasive alien species. Council of Europe Publishing, Strasbourg

Hijmans RJ, Cameron SE, Parra JL, Jones PG, Jarvis A (2005) Very high resolution interpolated climate surfaces for global land areas. Int J Climatol 25:1965-1978

IPCC (2013) Climate Change 2013. The physical science basis. Fifth assessment report of the Intergovernmental Panel of Climate Change

Keller RP, Lodge DM, Finnoff D (2007) Risk assessment for invasive species produces net bioeconomic benefits. Proc Natl Acad Sci 104:203-207

Kendal D, Williams NSG, Williams KJH (2012) A cultivated environment: exploring the global distribution of plants in 
gardens, parks and streetscapes. Urban Ecosyst 15:637-652

Klonner G, Dullinger I, Wessely J, Bossdorf O, Carboni M, Dawson W, Essl F, Gattringer A, Haeuser E, van Kleunen M, Kreft H, Moser D, Pergl J, Pyšek P, Thuiller W, Weigelt P, Winter M, Dullinger S (2017) Will climate change increase hybridization risk between potential plant invaders and their congeners in Europe? Divers Distrib. doi:10. 1111/ddi.12578

Kowarik I (1995) Time lags in biological invasions with regard to success and failure of alien species. In: Pyšek P, Prach K, Rejmánek M, Wade M (eds) Plant invasions-general aspects and special problems. SPB Academic Publishing, Amsterdam, pp 15-38

Křivánek M, Pyšek P, Jarošík V (2006) Planting history and propagule pressure as predictors of invasions by woody species in a temperate region. Conserv Biol 20:1487-1498

Kueffer C, Pyšek P, Richardson DM (2013) Integrative invasion science: model systems, multi-site studies, focused metaanalysis and invasion syndromes. New Phytol 200:615-633

Kühn I, Klotz S (2002) Floristischer Status und gebietsfremde Arten. Schriftenreihe Vegetationskunde 38:47-56

Kühn I, Brandl R, Klotz S (2004) The flora of German cities is naturally species rich. Evol Ecol Res 6:749-764

Lappen B (2009) Der Katalog. Baumschulen Lappen, Nettetal

Lehan NE, Murphy JR, Thorburn LP, Bradley BA (2013) Accidental introductions are an important source of invasive plants in the continental United States. Am J Bot 100:1287-1293

Lin BB, Meyers J, Beaty M, Barnett GB (2016) Urban green infrastructure impacts on climate regulation services in Sydney, Australia. Sustainability 8:788

Lindemann-Matthies P, Brieger H (2016) Does urban gardening increase aesthetic quality of urban areas? A case study from Germany. Urban For Urban Green 17:33-41

Lockwood JL, Cassey P, Blackburn T (2005) The role of propagule pressure in explaining species invasions. Trends Ecol Evol 20:223-228

Mack RN, Erneberg M (2002) The United States naturalized flora: largely the product of deliberate introductions. Ann Mo Bot Gard 89:176-189

Maggini R, Lehmann A, Zimmermann NE, Guisan A (2006) Improving generalized regression analysis for the spatial prediction of forest communities. J Biogeogr 33:1729-1749

Maurel N, Hanspach J, Kühn I, Pyšek P, van Kleunen M (2016) Introduction bias affects relationships between characteristics and naturalization success of ornamental alien plants. Glob Ecol Biogeogr 25:1500-1509

Meyer C, Weigelt P, Kreft H (2016) Multidimensional biases, gaps and uncertainties in global plant occurrence information. Ecol Lett 19:992-1006

Nehring S, Kowarik I, Rabitsch W, Essl F (2013) Naturschutzfachliche Invasivitätsbewertungen für in Deutschland wild lebende gebietsfremde Gefäßpflanzen. BfN-Skripten 352:1-202

Netzwerk Phytodiversität Deutschland \& Bundesamt für Naturschutz (2013) Verbreitungsatlas der Farn- und Blütenpflanzen Deutschlands. Landwirtschaftsverlag, Münster
Pergl J, Sádlo J, Petř́k P, Danihelka J, Chrtek J Jr, Hejda M, Moravcová L, Perglová I, Štajerová K, Pyšek P (2016a) Dark side of the fence: ornamental plants as a source for spontaneous flora of the Czech Republic. Preslia 88:163-184

Pergl J, Sádlo J, Petrusek A, Laštůvka Z, Musil J, Perglová I, Šanda R, Šefrová H, Šíma J, Vohralík V, Pyšek P (2016b) Black, grey and watch lists of alien species in the Czech Republic based on environmental impacts and management strategy. NeoBiota 28:1-37

Pflanzen Bruns (2013) Sortimentskatalog 2013-14. Joh. Bruns, Bad Zwischenahn

Pheloung PC, Williams PA, Halloy SR (1999) A weed risk assessment model for use as a biosecurity tool evaluating plant introductions. J Environ Manage 57:239-251

Pyšek P, Sádlo J, Mandák B, Jarošík V (2003) Czech alien flora and the historical pattern of its formation: what came first to Central Europe? Oecologia 135:122-130

Pyšek P, Danihelka J, Sádlo J, Chrtek J Jr, Chytrý M, Jarošík V, Kaplan Z, Krahulec F, Moravcová L, Pergl J, Štajerová K, Tichý L (2012a) Catalogue of alien plants of the Czech Republic (2nd edn): checklist update, taxonomic diversity and invasion patterns. Preslia 84:155-255

Pyšek P, Jarošík V, Hulme PE, Pergl J, Hejda M, Schaffner U, Vilà M (2012b) A global assessment of invasive plant impacts on resident species, communities and ecosystems: the interaction of impact measures, invading species' traits and environment. Glob Change Biol 18:1725-1737

R Core Team (2014) R: a language and environment for statistical computing. R Foundation for Statistical Computing, Vienna, Austria. http://www.R-project.org/

R Core Team (2016) R: a language and environment for statistical computing. R Foundation for Statistical Computing, Vienna, Austria. http://www.R-project.org/

Randall RP (2012) A global compendium of weeds, 2nd edn. Department of Agriculture and Food, Kensington

Razanajatovo M, Maurel N, Dawson W, Essl F, Kreft H, Pergl J, Kühn I, Pyšek P, Weigelt P, Winter M, van Kleunen M (2016) Plants capable of selfing are more likely to become naturalized. Nat Commun 7:13313

Reichard SH (1996) What traits distinguish invasive plants from non-invasive plants? In: California Exotic Pest Council, Symposium Proceedings

Rejmánek M, Richardson DM (2013) Trees and shrubs as invasive alien species-2013 update of the global database. Divers Distrib 19:1093-1094

Root TL, Price JT, Hall KR, Schneider SH, Rosenzweig C, Pounds JA (2003) Fingerprints of global warming on wild animals and plants. Nature 421:57-60

Schielzeth H (2010) Simple means to improve the interpretability of regression coefficients. Methods Ecol Evol 1:103-113

Seebens H, Blackburn TM, Dyer EE et al (2017) No saturation in the accumulation of alien species worldwide. Nat Commun 8:14435

Thuiller W, Lafourcade B, Engler R, Araújo MB (2009) BIOMOD - a platform for ensemble forecasting of species distributions. Ecography 32:369-373

Thuiller W, Georges D, Engler R, Breiner F (2016). biomod2: ensemble platform for species distribution modeling. $R$ 
package version 3.3-7. https://CRAN.R-project.org/ package $=$ biomod 2

Thum RA, Mercer AT, Wcisel DJ (2012) Loopholes in the regulation of invasive species: genetic identifications identify mislabeling of prohibited aquarium plants. Biol Invasions 14:929-937

Turbelin AJ, Malamud BD, Francis RA (2017) Mapping the global state of invasive alien species: patterns of invasion and policy responses. Glob Ecol Biogeogr 26:78-92

UN (2015) World urbanization prospects: the 2014 revision, United Nations, Department of Economic and Social Affairs, Population Division (ST/ESA/SER.A/366)

van Kleunen M, Dawson W, Maurel N (2015a) Characteristics of successful alien plants. Mol Ecol 24:1954-1968

van Kleunen M, Dawson W, Essl F et al (2015b) Global exchange and accumulation of non-native plants. Nature 525:100-103

Vilà M, Espinar JL, Hejda M, Hulme PE, Jarošik V, Maron JL, Pergl J, Schaffner U, Sun Y, Pyšek P (2010) Ecological impacts of invasive alien plants: a meta-analysis of their effects on species, communities and ecosystems. Ecol Lett 14:702-708
Wang Y, Bakker F, de Groot R, Wörtche H (2014) Effect of ecosystem services provided by urban green infrastructure on indoor environment: a literature review. Build Environ 77:88-100

Weber E (2003) Invasive plant species of the world: a reference guide to environmental weeds. CABI Publishing, Wallingford

Williamson M, Pyšek P, Jarošík V, Prach K (2005) On the rates and patterns of spread of alien plants in the Czech Republic, Britain and Ireland. Ecoscience 12:424-433

Wittenberg R (ed) (2005) An inventory of alien species and their threat to biodiversity and economy in Switzerland. CABI Bioscience Switzerland Centre report to the Swiss Agency for Environment, Forests and Landscape. The environment in Practice No. 0629. Federal Office for the Environment, Bern

Woodford DJ, Richardson DM, MacIsaac HJ, Mandrak NE, van Wilgen BW, Wilson JRU, Weyl OLF (2016) Confronting the wicked problem of managing biological invasions. NeoBiota 31:63-86 